8. Originator Remarks:

This engineering document is a test plan for new SY Farm annulus leak detectors (HNF-4634).
11. Receiver Remarks:
11A. Design Baseline Document? $\bigcirc$ Yes
( No

\begin{tabular}{|l|l|}
\hline $\begin{array}{l}\text { 2. To: (Receiving Organization) } \\
\text { DISTRIBUTION }\end{array}$ & $\begin{array}{l}\text { 3. From: (Originating Organization) } \\
\text { COGEMA Engineering Corp. }\end{array}$ \\
\hline $\begin{array}{l}\text { 5. Proj./Prog./Dept./Div.: } \\
\text { RPP/SY Farm annulus leak det. }\end{array}$ & $\begin{array}{l}\text { 6. Design Authority/Design Agent/Cog. Engr.: } \\
\text { RW Reed/R Abundo/JH Huber }\end{array}$ \\
\hline
\end{tabular}

\section{Related EDT No.:}

$\mathrm{N} / \mathrm{A}$

7. Purchase Order No.:

$\mathrm{N} / \mathrm{A}$

9. Equip./Component No.:

$\mathrm{N} / \mathrm{A}$

10. System/BIdg./Facility:

241-SY

12. Major Assm. Dwg. No.:

$\mathrm{N} / \mathrm{A}$

13. Permit/Permit Application No.:

$\mathrm{N} / \mathrm{A}$

14. Required Response Date:

$\mathrm{N} / \mathrm{A}$

15 DATA TRANSMITTED

\begin{tabular}{|l}
\hline (A) \\
ite \\
\hline 1 \\
\hline \\
\hline \\
\hline \\
\hline 16. \\
\hline
\end{tabular}

\begin{tabular}{l|l}
\hline $\begin{array}{c}\text { (A) } \\
\text { item } \\
\text { No. }\end{array}$ & (B) Document/Drawing No. \\
\hline
\end{tabular}

HNE -4634

(C) Sheet (D) Rev.

(E) Title or Description of Data Transmitted

(F)

(G)

(H)

(I)

Approval Reason Origi- Receiv-

Desig- for Trans- nator Dispo-

\begin{tabular}{l|l|l|l} 
nator & mittal & $\begin{array}{c}\text { stion } \\
\text { sition }\end{array}$ \\
\hline
\end{tabular}

0 TEST PLAN FOR SY FARM

ANNULUS LEAK DETECTOR.

\begin{tabular}{|c|}
\hline Approval Designator (F) \\
\hline E, S, Q, D OR N/A \\
(See WHC-CM-3-5, \\
Sec. 12.7) \\
\hline
\end{tabular}

17.

$\begin{array}{r}\hline \\ \hline\end{array}$

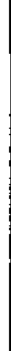

4 o
Originator
6
Rz arar

Authorized Representative for Receiving Organization

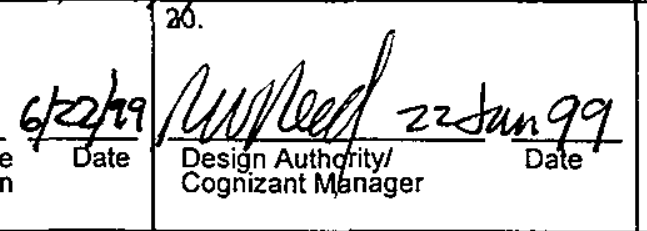

(K) Signature

(L) Date
(M) MSIN
Disposition (H) \& (i)

4. Reviewed no/comment

5. Reviewed w/comment

6 . Receipt acknowledged
21. DOE APPROVAL (if required)

Ctrl No.

Approved

Approved w/comments

Disapproved w/comments 


\title{
Test Plan \\ for \\ New SY Farm Annulus Leak Detectors
}

\author{
Robert Abundo \\ COGEMA Engineering Corp. \\ Richland, WA 99352 \\ U.S. Department of Energy Contract DE-AC06-96RL13200
EDT/ECN: 140135 UC: 2000
Org Code: S1700 Charge Code: 106773
B\&R Code: N/A Total Pages: 7

Key Words: test plan, leak detector, SY Farm, double shell tanks, ENRAF.

Abstract: This document provides a plan for testing a new annulus leak detection device in the annulus of the waste storage tank 241 SY-102.

TRADEMARK DISCLAIMER. Reference herein to any specific commercial product, process, or service by trade name, trademark, manufacturer, or otherwise, does not necessarily constitute or imply its endorsement, recommendation, or favoring by the United States Government or any agency thereof or its contractors or subcontractors.

Printed in the United States of America. To obtain copies of this document, contact: Document Control Services, P.O. Box 950, Mailstop H6-08, Richland WA 99352, Phone (509) 372-2420; Fax (509) 376-4989.
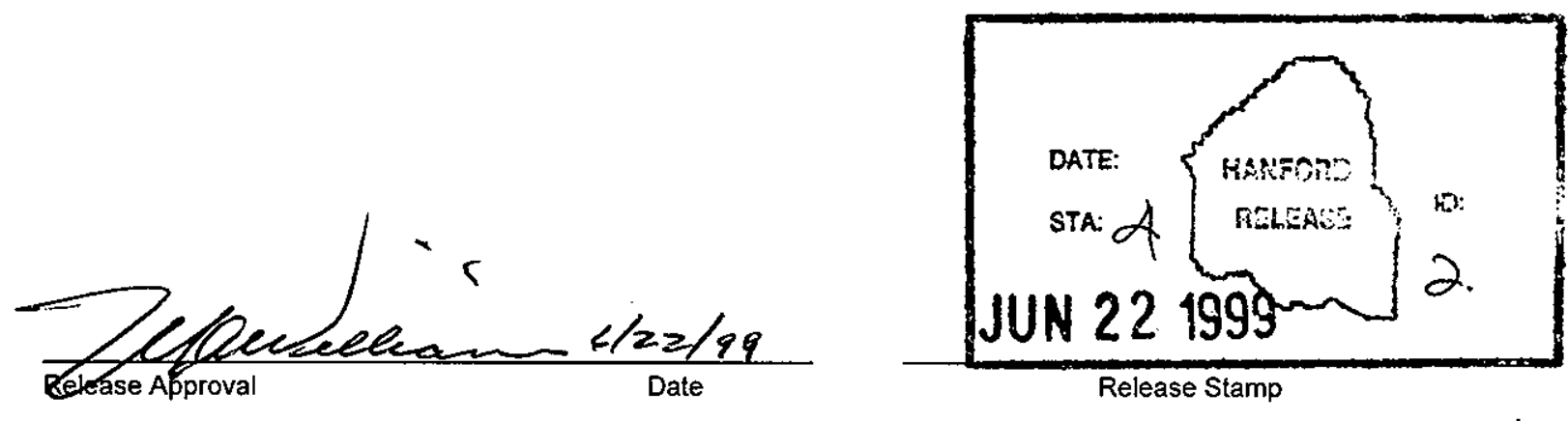

Approved For Public Release 


\section{TEST PLAN FOR NEW SY FARM ANNULUS LEAK DETECTORS}

\section{TABLE OF CONTENTS}

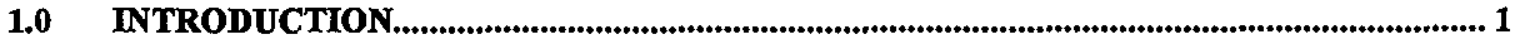

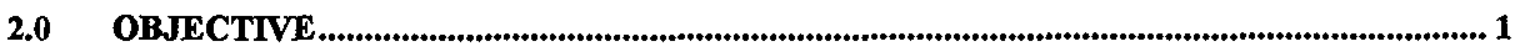

3.0 SCOPE

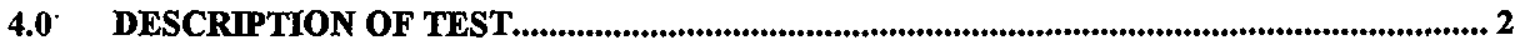

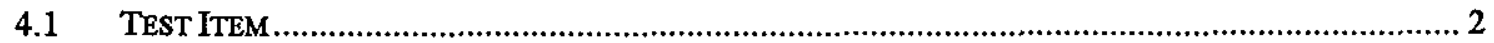

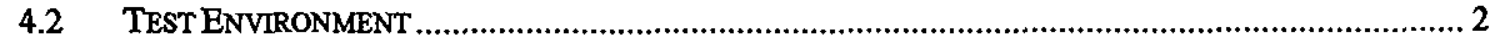

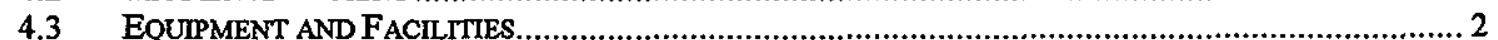

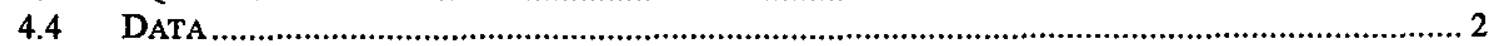

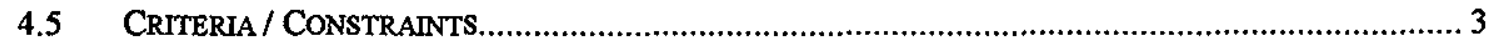

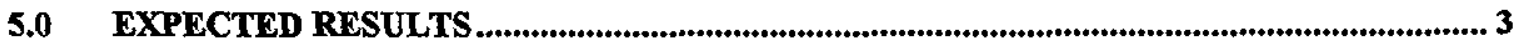

6.0 TEST PROCEDURE

7.0 SAFETY

8.0 QUALITY ASSURANCE

9.0 ORGANIZATION AND FUNCTION RESPONSIBILITIES.................................................. 4

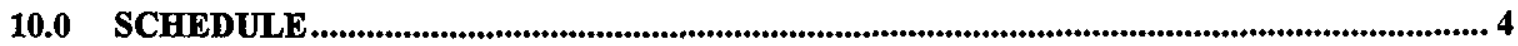

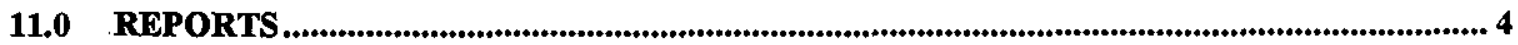

12.0 REFERENCES 


\section{Test Plan for New SY Farm Annulus Leak Detectors}

\subsection{INTRODUCTION}

This document is a plan for testing a newly installed annulus leak detector (ALD) in the annulus of an SY Tank, specifically 241-SY-102. One Enraf-Nonius 854 ATG level gauge will be initially installed for verification that the gauge will meet the requirements for annulus leak detection. Upon completion of a successful test, eight additional EnrafNonius 854 ATG level gauges will be installed in the three SY Farm Double Shell Tanks (DST). There will be a total of nine level gauges installed in the SY tank Farm when work is completed. The three annulus leak detectors in each tank will be located approximately 120 degrees apart.

The 854 operates on the principal of buoyancy and uses a displacer suspended by a small diameter steel alloy wire. In liquid, the 854 measures level to an accuracy of 0.04 inches with a repeatability of 0.004 inches. For leak detection application it is necessary to detect a change from dry floor to some minimum level of liquid accumulation. Since the principal of operation is buoyancy, sufficient liquid must be present to "float" the displacer before a change in level is detected. Testing of this minimum detectable level is the first step in this activity (Scaief 99). The displacer was redesigned for increased sensitivity by using a formula given by the manufacturer. For reference, see "Instruction manual series 854 ATG level gauge."

\subsection{OBJECTIVE}

The objective of this testing is to demonstrate that the Enraf-Nonius 854 ATG level gauge is stable and will not cause spurious alarms at the TMACS operator stations. Also that there are no unforeseen obstacles in its use as a leak detector.

\subsection{SCOPE}

This test includes preliminary testing and monitoring of one Enraf 854 level gauge in the annulus of SY-102. The gauge will be connected via an Enraf Communication Interface Unit (CIU) to the Tank Monitor and Control System (TMACS).

During the testing phase the device will not be used for satisfying the requirements of Limiting Conditions for Operation (LCO) 3.2.6 as defined in the Technical Safety Requirements (TSR). 


\subsection{DESCRIPTION OF TEST}

\subsection{Test Item}

Enraf-Nonius 854 ATG level gauge with SPU II hard alarm output contact card installed, and a modified displacer, which is suspended by a wire on a measuring drum. A force transducer measures the weight of the displacer. The actual output value of the force transducer is compared with a desired value for the apparent weight of the displacer. If a discrepancy exists between measured and desired value a software control adjusts the position of the stepper motor.

A modified displacer with a larger base diameter was confirmed to achieve the acceptable alarm level ${ }^{1}$. The acceptable alarm level is 0.25 with a -0.125 to +0.25 tolerance (Huber 99).

\subsection{Test Environment}

The level gauge will be installed on Riser-033 of tank 241-SY-102, under normal ambient conditions. The design ambient temperature ranges for the equipment is:
Outdoor
$-25 \mathrm{~F}$ to $115 \mathrm{~F}$
Buildings
$50 \mathrm{~F}$ to $95 \mathrm{~F}$

The Enraf 854 is rated for operation over a temperature range of $-40 \mathrm{~F}$ to $185 \mathrm{~F}$.

\subsection{Equipment and Facilities}

The test unit will be installed in Riser-033 of tank 241-SY-102. An ENRAF CIU will be installed in instrument building 241-SY-271.

No special tools are needed for the initial test. This test is to see if the Enraf level gauge is stable and the output does not drift.

\subsection{Data}

Test data are collected and stored by a computer (via TMACS), which later can be used for reference. The frequency at which data are stored is every one-minute. This testing process is scheduled for 30 days.

\footnotetext{
${ }^{1} \mathrm{H}-2-817634$ part \#89 as added by ECN 649073
} 


\subsection{Criteria / Constraints}

No alarms are expected. If however, an alarm has occurred before the end of the 30-day trial, the cognizant engineer will review the test results and determine what caused it. The test will continue unless otherwise halted by the cognizant engineer.

Prior to starting the test, all needed instruments must be checked for functionality and calibrated as required.

\subsection{EXPECTED RESULTS}

A successful test would be if there are no unexplained spurious alarms and the level remains constant.

\subsection{TEST PROCEDURE}

Before starting any test with the Enraf level gauge, make sure all required equipment is properly checked.

The following procedure steps assume that the test performer is familiar with the EnrafNonius 854 ATG level gauge and that the "Instruction manual series 854 ATG level gauge" and "Instruction manual SPU II Hard alarm output contacts" are available for reference.

1.0 Follow the installation and setup procedure steps for the level gauge specified in the work package $2 \mathrm{~W}-99-738 / \mathrm{M}$.

2.0 Perform TMACS ATP WHC-SD-WM-ATP-023, Rev. 7.

3.0 Engineer to periodically review TMACS history file during the test.

4.0 Run test for 30 days.

\subsection{SAFETY}

No unique or unusual industrial, radiological, chemical, fire, release of energy, or criticality safety hazards is involved with performing or supporting these tests. 


\subsection{QUALITY ASSURANCE}

A Quality Assurance representative shall review this document as well as the test report when it is prepared. QA will also be involved in shop ATP testing as well as the TMACS ATP.

QA will be present during the ATP setup and as required.

\subsection{ORGANIZATION AND FUNCTION RESPONSIBILITIES}

The following group will perform the task assigned to each one.

Maintenance - Maintenance personnel will perform the initial installation of the EnrafNonius 854 level gauge and inspect it for functionality.

Operations - The Operations personnel will do any routine (or round) work for the level gauge.

Process Control - Process control personnel are responsible for setting up TMACS (Tank Monitoring and Control System) to read the level gauge and making sure that data are gathered and stored.

Quality Assurance-QA will be responsible for reviewing test results and accepting CGI form.

Engineering - Engineering (COGEMA / NHC / LMHC) is responsible for providing the design and supporting the installation, test and the maintenance of the level gauge.

\subsection{SCHEDULE}

Testing will start after this Test Plan is approved and after the construction work in the field is complete. Testing will last for 30 days, after which the test data will be evaluated and the test report prepared.

\subsection{REPORTS}

A Test Report will be generated after all testing is done. 


\subsection{REFERENCES}

Enraf Inc., Instruction Manual Series 854 ATG Level Gauge, Part No. 4416.220, Version 2.2, March 1996 (See CV-31560, vendor information file).

Huber, J. H., Test report for ENRAF annulus leak detector development, HNF-4328, Revision 0, dated May 25, 1999.

Scaief III, C. C., Engineering task plan for new SY Farm annulus leak detectors, TWR4092, Revision 0, dated June 1, 1999. 


\section{DISTRIBUTION SHEET}

To

DISTRIBUTION

Project Title/Work Order

TEST PLAN EOR NEW SY FARM ANNULUS LEAK DETECTORS.

Name

R. Abundo

M. H. Brown M. Mnan

K. E. Carpenter

G. M. Crummel

G. W. Gault

J. H. Huber

L. S. Krogsrud

D. C. Larsen

R. E. Raymond

R. W. Reed

M. D. Rickenbach

C. C. Scaief III

R. L. Schlosser

R. R. True

W. E. Willingham

R. E. Larson

T. C. Oten

From

Robert Abundo

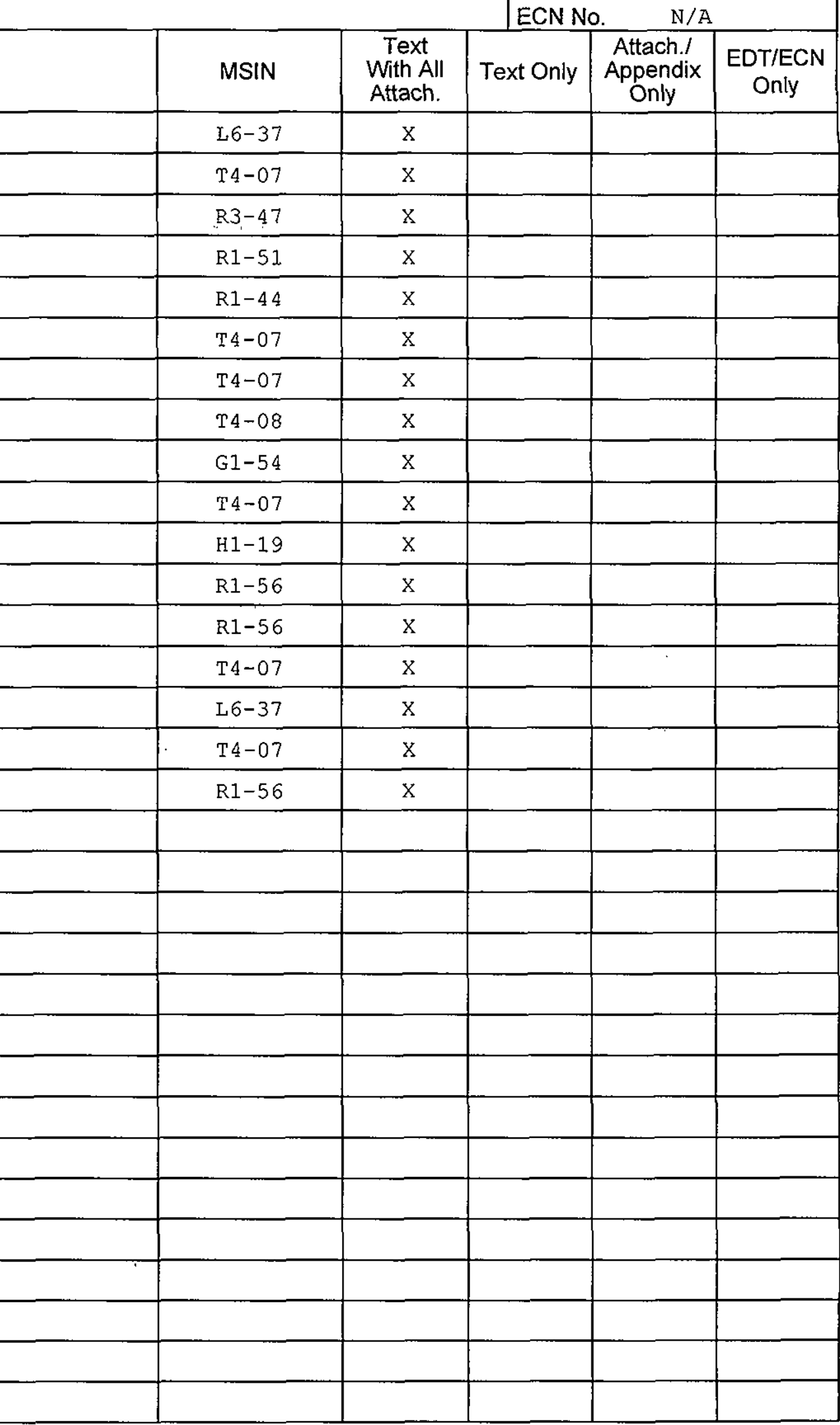

Page 1 of 1

Date $\quad 6 / 17 / 99$

EDT No. $\quad 140135$

ECN No. N/A 